\title{
A Case study on the management of Obsessive Compulsive Disorder (OCD) in Ayurveda
}

\author{
Case Report
}

\author{
Niranjan $S^{1^{*}}$, Swapna Swayamprava ${ }^{2}$ \\ 1. Assistant Professor, Department of Kayachikitsa and Manasaroga, \\ 2. Assistant Professor, Department of Agadatantra, \\ SDM College of Ayurveda, Udupi, Karnataka
}

\begin{abstract}
Obsessive-compulsive disorder (OCD) is a type of anxiety disorder in which a person has unreasonable thoughts and fears (obsessions) that lead him to engage in repetitive behaviors (compulsions). A person affected with OCD may realize that his obsessions are not reasonable and may try to ignore or stop them, but he is driven to perform compulsive acts in an effort to ease his distress. OCD usually centers on themes which lead to ritualistic behaviour that ultimately affects the person's life. In this paper a case study of OCD with the symptoms of obsessions of contamination associated with mild depression and Parkinson's disease is discussed which was successfully treated with some Ayurvedic formulations for about 2 months.
\end{abstract}

Keywords: Obsessions, Compulsions, OCD, Atattvabhinivesha, Bhutonmada

\section{Introduction}

Obsessive Compulsive Disorder (OCD) as the name suggests has two domains in it viz., Obsession and Compulsion. An obsession is a recurrent and intrusive thought, feeling, idea or sensation. A compulsion is a conscious, standardized, recurrent thought or behavior, such as counting, checking, or avoiding. Obsessions increase a person's anxiety, whereas carrying out Compulsions reduces a person's anxiety. However, when a person resists carrying out a Compulsion, anxiety is increased. A person with OCD generally realizes the irrationality of the obsessions and experiences both the obsessions and the compulsions as ego-dystonic. OCD can be a disabling disorder, because the obsessions can be time-consuming and can interfere significantly with the person's normal routine, occupational functioning, usual social activities, or relationships with friends and family members (1).

\section{Epidemiology:}

OCD affects $2 \%$ to $3 \%$ of the population and it is estimated that OCD is the fourth most common mental illness. There is an equal prevalence among males and females. Although the mean age of onset is between 22 and 36 years, it can occur in any age group and males tend to develop the disorder earlier than females. The disorder appears with similar prevalence

\footnotetext{
*Corresponding Author:

\section{Niranjan S}

Assistant Professor,

Department of Kayachikitsa and Manasaroga,

SDM College of Ayurveda, Udupi, Karnataka.

Mobile No.: +91-9341599604

E-mail: niranjan.doc@gmail.com
}

rates and symptom presentations across cultures. However, there can be some cultural specificity to the content of obsessions. OCD has a significant impact on quality of life and can greatly impair one's level of functioning. The World Health Organization has estimated that OCD is among the top 20 causes of illness-related disability for people between the ages of 15 and 44 (2).

\section{Signs \& symptoms}

The presentation of obsessions and compulsions is heterogeneous and numerous symptoms are seen accordingly. The symptoms of an individual patient may overlap and change with time, but OCD has four major symptom patterns. The most common pattern is an Obsessions of Contamination, followed by Washing or accompanied by compulsive avoidance of the presumably contaminated object. The feared object is often hard to avoid (for example, faeces, urine, dust or germs). Patients may literally rub the skin off their hands by excessive hand washing. Patients with Contamination obsessions usually believe that the contamination is spread from object to object or person to person by the slightest contact (3).

The second most common pattern is an Obsession of doubt, followed by a Compulsion of Checking. The Obsession often implies some danger of violence (such as forgetting to turn off the stove or not locking a door). The checking may involve multiple trips back in to the house to check the stove, for example. The patients have an Obsessional self doubt, as they always feel guilty for having forgotten or committed something (3).

The third most common pattern is one with merely intrusive obsessional thoughts without a 
compulsion. Such obsessions are usually repetitious thoughts of some Sexual or Aggressive act that is reprehensible to the patient (3).

The fourth most common pattern is the Need for Symmetry or Precision, which can lead to a Compulsion of Slowness. Patients can literally take hours to eat a meal or to shave their faces (3).

Generally OCD is seen as co-morbid condition of other psychiatric disorders and is not seen as a separate entity. OCD encompasses a broad range of symptoms that represent multiple psychological domains, including perception, cognition, emotion, social relatedness and diverse motor behaviors. OCD is a multi dimensional and etiologically heterogeneous condition. Two individuals with OCD may have totally different and non overlapping symptom patterns.

\section{Ayurvedic view point}

There is a branch called "Bhoota Vidya" (one among the eight branches) in Ayurveda that deals with Ayurvedic Psychiatry. If we scrutinize the Ayurvedic classical texts we won't get any direct or exact correlations of OCD in Ayurvedic texts. However, some references are present which mimic with the symptoms of OCD. One among them is Atattvabhinivesha wherein the person sees predominantly the unreal as real and vice versa as well as the unwholesome as wholesome and vice versa. This disease is said to be Mahagada which states the severity of the disease (4).

Bhutonmada is another condition wherein few symptoms of some Graha rogas resemble the clinical symptoms described for OCD. For example,

Deva graha jushta purusha lakshanas like Shuchi (Excessive cleanliness), Samskrita vaadinam (Speaking cultured language or Excessive concern of saying the just right thing), Deva dvija guru bhaktam (Excess morality) (5).

Rishi graha jushta purusha lakshanas like Snaana (Excessive bathing), Shuchi (Excessive cleanliness), Vivikta sevinam (Preference to Solitude) (5).

Gandharva graha jushta purusha lakshanas like Shouchacharam (cleanliness or ritualistic) etc (5).

\section{Treatment}

The main line of treatment in OCD as in Ayurveda is Daiva vyapashraya (sometimes if the disease is very severe in condition), Sattvavajaya (jnana, vijnana, etc i.e., various psychotherapeutic techniques) along with Yukti vyapashraya chikitsa. If the OCD patient shows doshaja symptoms (Bhutonmada with Nija Unmada), Yukti vyapashraya gets importance.

\section{Case details}

A male patient aged about $64 \mathrm{yrs}$, who is a retired school teacher with middle socio-economic status background came to our OPD (OPD No. 43068) on $9^{\text {th }}$ June 2013 with the persisting complaints of repeatedly washing the hands, feeling that his hands are dirty, excessive anger outbursts, fear of falling down at times while walking as if someone is pushing him from behind, fine tremors in the hands and reduced strength since 4 months. The onset was gradual. The subject was apparently normal 4 months back and is completely unaware of the reason for the change in his behavior. The diagnosis was made as per DSM-IV TR diagnostic criteria for OCD. The details of the obsessions and compulsions are as follows - He used to spend approximately 2-3 hours in total in a day on washing and cleaning the hands. The thought of dirty hands was interfering with his day-to-day routine activities but somehow it was manageable. The obsessions as well as the compulsions were causing him little distress as there was much resistance and control over the obsessions and compulsions. Because of the shyness of his behavior he was feeling difficult in mingling with the people and was keeping himself alone in his home, not interested in any activities. And along with these he also had the symptoms like worthlessness, hopelessness, reduced enthusiasm, reduced interest in day to day activities, getting irritated very easily even for silly aspects. Along with this the subject was also having fine tremors in the hands. On examination, nothing abnormalities were detected in Respiratory system, Cardiovascular and Central nervous systems. The subject had typical short and rapid steps (typical parkinsonian gait) and cogwheel rigidity was seen. On detailed history taking and clinical examination (including the mental status examination) the case was diagnosed as having Obsessive Compulsive Disorder (obsession of contamination) along with mild depression and Parkinsonism. He had been underwent cardiac bypass surgery 2 years back and was continuing the conservative medication. The routine haematological investigations were within normal levels. The subject was non alcoholic, non smoker, non-hypertensive and non-diabetic. His marital history, family history and occupational history were satisfactory. By considering this condition to be the 'Bhutonmada' with Nijonmada associated with kampavata and as vata-kapha lakshanas were seen predominantly in this case, samshamana line of treatment, a form of Yukti vyapashraya chikitsa was adopted.

\section{Materials and methods}

The following formulations were prescribed

1. Tab. Manasamitra vati - 1 tid

2. Combination of churnas of 4 drugs namely

a. Shankhapushpi (Convolvulus pluricaulis Chois) 1 part

b. Sarpagandha (Rauwolfia serpentina Benth ex Kurz.) - 1 part

c. Gokshura (Tribulus terrestris Linn.) - 1 part

d. Jatamamsi (Nardostachys jatamansi DC) - 1/2 part

2 gms tid with cow's ghee before food

3. Saraswatarishta $-15 \mathrm{ml}$ tid after food

4. Kapikachchu (Mucuna prurita Hook.) churna - 


\section{$2.5 \mathrm{gm} \mathrm{bd}$}

5. The decoction prepared out of Aragwadha (Cassia fistula Linn) twak churna $-90 \mathrm{ml}$ bd before food

Duration: 2 months

\section{Assessment criteria}

Assessment was done on the basis of Yale Brown Obsessive Compulsive Scale (Y-BOCS), a 5 point scale which is an indicative of degree of severity of obsessions and compulsions. Assessment was taken before treatment and every $15^{\text {th }}$ day of the treatment schedule. Apart from the oral medication simple counseling was given in the form of reassurance on every week.

\section{Observation and results}

The medication was done for 2 months. In this regard the following observations were recorded. These are the scores of each criterion of obsession (table no. 1) and compulsion (table no. 2) before the treatment and day wise assessment during the therapy as mentioned below.

Table no. 1: Effect of therapy on Obsessions

\begin{tabular}{|c|c|c|c|c|c|}
\hline \multirow{2}{*}{ Obsessions } & \multirow{2}{*}{$\mathbf{B T}$} & \multicolumn{4}{|c|}{ AT(day wise) } \\
\cline { 3 - 6 } & $\mathbf{1 5}^{\text {th }}$ & $\mathbf{3 0}^{\text {th }}$ & $\mathbf{4 5}^{\text {th }}$ & $\mathbf{6 0}^{\text {th }}$ \\
\hline $\begin{array}{c}\text { Time spent } \\
\text { on obsession }\end{array}$ & 2 & 2 & 1 & 1 & 0 \\
\hline $\begin{array}{c}\text { Interference } \\
\text { from } \\
\text { obsession }\end{array}$ & 2 & 2 & 1 & 1 & 0 \\
\hline $\begin{array}{c}\text { Distress from } \\
\text { obsession }\end{array}$ & 1 & 1 & 1 & 0 & 0 \\
\hline $\begin{array}{c}\text { Resistance to } \\
\text { obsession }\end{array}$ & 1 & 1 & 1 & 1 & 0 \\
\hline $\begin{array}{c}\text { Control over } \\
\text { obsession }\end{array}$ & 1 & 1 & 1 & 0 & 0 \\
\hline
\end{tabular}

Table no. 2: Effect of therapy on Compulsions

\begin{tabular}{|c|c|c|c|c|c|}
\hline \multirow{2}{*}{ Compulsions } & \multirow{2}{*}{$\mathbf{B T}$} & \multicolumn{4}{|c|}{ AT (day wise) } \\
\cline { 3 - 6 } & $\mathbf{1 5}^{\text {th }}$ & $\mathbf{3 0}^{\text {th }}$ & $\mathbf{4 5}^{\text {th }}$ & $\mathbf{6 0}^{\text {th }}$ \\
\hline $\begin{array}{c}\text { Time spent on } \\
\text { compulsions }\end{array}$ & 2 & 2 & 1 & 1 & 0 \\
\hline $\begin{array}{c}\text { Interference } \\
\text { from } \\
\text { compulsions }\end{array}$ & 2 & 2 & 1 & 0 & 0 \\
\hline $\begin{array}{c}\text { Distress from } \\
\text { compulsions }\end{array}$ & 1 & 1 & 1 & 0 & 0 \\
\hline $\begin{array}{c}\text { Resistance to } \\
\text { compulsions }\end{array}$ & 1 & 1 & 0 & 0 & 0 \\
\hline $\begin{array}{c}\text { Control over } \\
\text { compulsions }\end{array}$ & 1 & 1 & 0 & 0 & 0 \\
\hline
\end{tabular}

During the $1^{\text {st }}$ assessment after 15 days there was no improvement seen. After one month, the time spent on obsessions and compulsions was reduced from 2-3hrs/ day to $0-1 \mathrm{hr} /$ day. Interference to daily activities was reduced from moderate to mild and control over obsession and compulsions were also improved. After the 2 months of treatment complete reduction in the symptoms of OCD was seen. Even the mild depression symptoms were also reduced markedly. But the fear of falling down while walking was persisted as it was earlier.

\section{Discussion}

As OCD is psychological and anxiety related disorder where body-mind role is very important to be handled. According to Ayurvedic patho-physiology, obsessions and repetitive compulsive acts are believed to be due to a disturbed or increased vata dosha. In this subject, as the kapha dosha was also involved vata kapha hara drugs were administered with the better expectation of the results. The reason behind the selection of these drugs is as follows:

Manasamitra vati - it is a herbomineral product having the neuro protective properties and also helps in the correction of cognitive deficits (6).

Saraswatarishta - it is a good nervine tonic, promotes intelligence and cognition enhancer. Its ingredients are combination of anti-oxidant, immune stimulant and anti-inflammatory that help in memory enhancing (7).

Shankhapushpi (Convolvulus pluricaulis Chois) brain tonic (8), psycho-stimulant (8), tranquilizer (8), anti-stress (9), anti-anxiety (9), anti depressant (9), best medhya dravya

Sarpagandha (Rauwolfia serpentina Benth ex Kruz.) - sedative, tranquilizer, useful in both psychotic and neurotic cases, insomnia (10).

Jatamamsi (Nardostachys jatamansi DC) - brain tonic, anti depressant, sedative and relaxing effects, adaptogen, neuroprotective (11).

Aragwadha (Cassia fistula Linn.) - kaphahara and vatanulomaka, good in vatavyadhis wherein the kapha dosha involvement is seen. As the subject was having kapha vata symptoms this decoction is used.

Kapikachchu (Mucuna prurita Hook.) - Apart from aphrodisiac property it contains levodopa and hence used as an adjuvant in Parkinson's disease (12).

When we look into the qualities of the drugs used in this combination of formulations most of the drugs are anti-stress, anti-anxiety, tranquilizer, brain tonic, immune stimulant. Hence, these drugs in combination were helpful in reducing the anxiety level and depression in the case of OCD.

\section{Conclusion}

As this case had mild degree of OCD symptoms only the oral medications along with the simple counseling in the form of reassurance helped him in his 
improvement. If not treated at this level it might turn to moderate to severe degree of OCD wherein without specific psychotherapy like Behaviour therapy, response prevention, cognitive behavior therapy etc it becomes highly difficult to control the case with only oral medications.

\section{References}

1. Sadock J. Benjamin, Sadock A. Virginia; Obsessive Compulsive Disorder; Kaplan \& Sadock's Synopsis of Psychiatry; $10^{\text {th }}$ edition; Philadelphia, USA; Lippincott Williams \& Walkins publication; c2007; 604

2. http://bestpractice.bmj.com/best-practice/ monograph/362/basics/epidemiology.html BMJ Best practice, BMJ Publishing group Ltd 2015, updated on December 152014 [accessed 3 August 2015, 6 PM]

3. Sadock J. Benjamin, Sadock A. Virginia; Kaplan \& Sadock's Synopsis of Psychiatry; $10^{\text {th }}$ edition; Philadelphia, USA; Lippincott Williams \& Walkins publication; c2007; 608,609

4. Agnivesha, Charaka, Dridhabala; Charaka Samhita with Ayurveda Dipika commentary, Chikitsa Sthana, Apasmara Chikitsadhyaya 10/60; In: Vd. Jadavaji Trikamji Acharya, editor; $4^{\text {th }}$ edition, Chaukhambha Sanskrit Sansthan, Varanasi, 1994, p477

5. Agnivesha, Charaka, Dridhabala; Charaka Samhita with Ayurveda Dipika commentary, Chikitsa Sthana, Unmada Chikitsadhyaya 9/21; In: Vd. Jadavaji Trikamji Acharya, editor; $4^{\text {th }}$ edition, Chaukhambha Sanskrit Sansthan, Varanasi, 1994, p470
6. Thirunavukkarasu SV, Upadhyay Lokesh, Venkataraman S. Effect of Manasamitra vatakam, an Ayurvedic formulation, on Aluminium-induced Neurotoxicity in rats; Trophical Journal of Pharmaceutical Research, February 2012; 11 (1); 7583

7. http://www.bimbima.com/health/post/2012/09/05/ ayurveda-saraswatarishta-for-insomnia-and-nervoussystem.aspx [as cited 29 July 2015, 6.30 pm]

8. Velishala Hindu, Shankhapushpi - A short review; International Research Journal of Pharmacy 2012, 3 (1), http://www.irjponline.com/admin/php/ uploads/794_pdf.pdf, Page no. 81 - 83 [accessed 3 August 2015,7 pm]

9. Neeraj K. Sethiya et al, Comparative evaluation of commercial sources of indigenous Medicine Shankhpushpi for anti-stress potential - A preliminary study Pharmacologyonline 2: 460-467 (2009) available on http:// pharmacologyonline.silae.it/files/archives/2009/ vol2/045.Neeraj.pdf [cited on 3 August 2015, 7.15 $\mathrm{pm}]$

10.http:/www.homeremediess.com/medicinal-herbsarpagandha-uses/ Medicinal herb Sarpagandha uses and pictures (Rauwolfia serpentina) [as cited on 3 August 2015, 8 pm]

11.http:/examine.com/supplements/nardostachysjatamansi/ [as cited on 3 August 2015, 8.50 pm]

12.http://www.himalayawellness.com/products/ pharmaceuticals/kapikachhu.htm [as cited on 3 August 2015, 9 pm]. 